\title{
Learning Outcomes in Science Among Elementary Level Students
}

\author{
Hem Raj $^{1^{*}}$ and Fatma Gausiya ${ }^{2}$ \\ ${ }^{1 *}$ Minerva College of Education, Kangra, Himachal Pradesh-176402, India \\ ${ }^{2}$ Research Scholar, Department of Education, Panjab University, Chandigarh-160014, India
}

Email: rajbharmouri@gmail.com ${ }^{1 *}$, fatma_gausiya10@yahoo.co.in ${ }^{2}$

\section{ARTICLE INFORMATION}

Received: June 12, 2019

Revised: July 30, 2019

Accepted: August 20, 2019

Published Online: September 04, 2019

Keywords:

Learning Outcomes, Science, Elementary

Level Students

\begin{abstract}
The evolution in field of science has led to technological advancement in present century and has made the human to think and behave in more scientific way. Inadequate knowledge of science and how it functions may affect the efficient functioning of humans, and thus this demands to have a society where students are exposed to scientific knowledge. Exposure to science from the foundations years in schools is not to develop each child into a scientist but it is necessary to develop scientific attitude in them to find out the truth by experiencing, observing and questioning what captivates their interest and attention.

Hence, the present study focused on learning outcomes in science among elementary school students. The present study focuses on achievement of elementary school students in science and also compares the differences on the basis of the type of school and gender. The population for the study consisted of students from residential, government and private schools of Chandigarh. Sample was randomly selected including 35 students from class VIII from each type of school. The self-developed standardized Science Achievement Test (SAT) was used as an instrument for data collection. Data was analyzed using percentage, t-test and one way ANOVA with SPSS (version 21). The findings of the study revealed that 39 percent of students scored above average, 23 percent scored average and 38 percent scored below average in SAT. Male and female students do not differ on learning outcome in science but on the basis of type of school, students of residential school performed better in SAT as compared to government and private school students. It is recommended that various factors affecting learning outcomes in science should be explored to improve the Achievement in Science.
\end{abstract}

\section{Introduction}

The present century is developing at very fast rate due to the evolution in science. The technological advancement had led humans to think and behave in more scientific way, because inadequate scientific knowledge might interfere their efficient functioning. Science has played a tremendous role in our lives during the last century and is now changing our entire existence in such important areas as health, agriculture, communication, transportation, industry and power etc. Modern world has been created by science and is being maintained by it. Obviously, therefore, science must find a respectable place in school curriculum. All over the world, this feeling is being generated that the knowledge of science inculcates among the pupils a specific procedure for attacking a problem. There are various reasons which make it essential for the inclusion of this subject in curriculum as follows:

- To emphasise the utility of science in routine life and foster scientific attitudes.

- To build an environment that promotes more certainty in using the principles, theories and practices of science.

- To make learner learn about various natural processes and development.

- To realise the empirical nature of science and how these methods are interrelated across various disciplines of science (National Research Council (2007).

These reasons helps to understand why and how the inclusion of science as a subject in curriculum is essential and also enable learners during the foundation years in school to understand the place science holds as a discipline and thus its importance 
of learning science. The place that science hold in the curriculum and at large in our daily life not only benefits the society as it would develop the citizens with critical thinking and scientific attitude towards life, but also brings the responsibility for the teachers to work in this direction (Ungar, 2010). Exposure to science from the foundations years in schools is not to develop each child into a scientist but it is necessary to develop scientific attitude in them to find out the truth by experiencing, observing and questioning what captivates their interest and attention. The Indian Education Commission (1964-66) report by Kothari (1966) has pointed out that our science education is in bad shape and it becomes worse if we fail to reckon with the explosion of knowledge. To meet this immediate threat, the commission recommended upgrading the school curricula by research in curriculum development, the revision of textbooks and teaching-learning material. With some of the developments already implemented, the present study was undertaken to study the learning outcomes in science among elementary school children. As there have been many initiatives to improve learning outcomes of students, so an assessment of learning outcomes will help to understand if the changes done in field of education have been successful, and also identify the gap, if any, exist in policy making and implementation. The study also focused on assessing if there are differences in leaning outcome of male and female students, as many studies by various researchers have reported similar learning outcome of boys and girls (Olagunju, 1998; Olasehinde \& Olatoye, 2014) but many others have reported contradicting results (Aremu, 1999; Okwo \& Otunba, 2007; Raimi \& Adeoye, 2002; Toh, 1993). Further, since all the CBSE schools follow same syllabus, a comparison has been sought among government, private and residential schools, to assess how they differ on learning outcomes.

\section{Objectives}

1. To study the Achievement of students in Science.

2. To compare mean scores of Science Achievement Test of Male and Female students.

3. To compare mean scores of Science Achievement Test of Government, Private and Residential school students.

\section{Hypotheses}

1. There is statistically no significant difference in mean scores of Science Achievement Test of Male and Female students.

2. There is statistically no significant difference in mean scores of Science Achievement Test of Government, Private and Residential school students.

\section{Methods \& Procedure}

Descriptive method of research was employed for the present study using survey method. For proceeding with the data collection, firstly the permission was taken from DEO through proper channel. On getting the permission from $\mathrm{DEO}$ random sampling technique was used for selecting schools. Randomly one school of each type i.e. residential, government and private was selected using random number table from 106 government, 69 private and one residential schools. The selected government, private and residential schools were affiliated to CBSE and were located in main city of Chandigarh. These schools followed English as medium of instruction. The teacher-student ratio of government and private school was similar with 1:45 but this ratio varied for residential school as 1:35.

The population for the study consisted of students from residential, government and private schools of Chandigarh. After selection of these schools the researchers personally visited the school and met principal of the selected schools to get permission for data collection from students. The principals were explained the purpose of the research. After getting the permission, researchers met the class teachers and explained them the motive of conducting the research and requested for permission to interact with students. With permission of teachers, researchers interacted with students and explained students that students had the choice to not participate in the study, if they do not wish to. From the students who gave their consent to fill the Science Achievement Test (SAT), from each school 35 students were selected randomly by using lottery method from class VIII. The SAT was personally administered by the researchers. Each student was provided with the SAT and were given 5 mins to read the instructions carefully and ask doubts, if any. After 5 minutes they were asked to start the test that has to be completed in an hour time.

The self-developed standardized Science Achievement Test (SAT) was used for data collection. 
SAT was developed based on the science syllabus prescribed by NCERT, which students had studied in the previous class. It consisted of 120 objective type questions objective type questions which covered all six levels of blooms taxonomy i.e. remembering, understanding, applying, analyzing, evaluating and creating. The tool included $43 \%$ items relating to remembering, $28 \%$ understanding, $12 \%$ applying, $8 \%$ analyzing, $3 \%$ evaluating and $3 \%$ creating. It has been taken care that with increasing level of difficulty of items as per Blooms taxonomy the number of items for each level were minimized. The tool included various types of questions like multiple choice questions, match the columns, fill in the blanks, true-false, give one word, complete with hint and odd one out. The items included in the tool had difficulty value between $16 \%$ - 84\% (Sahu, 2012) and the value of discrimination index was more than .10 (Earnest et al., 2018). The validity of the tool was established by calculating Index of Suitability and all items had value equal or more than .80. Retest method was used to establish the reliability and coefficient of correlation was found to be .870 . For time duration, SAT was administered on a different sample of same age group studying in class VIII and the average time taken by most of the students was finalized as the time to complete the test i.e. 60 minutes.

After completion of the test, it was collected and researchers manually scored each test. The scores obtained by each student was entered in MS excel sheet. These scores of the students in SAT were categorized as per CBSE norms.

\begin{tabular}{|c|c|}
\hline Super & $91-100 \%$ \\
\hline Best & $81-90 \%$ \\
\hline Very good & $71-80 \%$ \\
\hline Good & $61-70 \%$ \\
\hline Fine & $51-60 \%$ \\
\hline Average & $41-50 \%$ \\
\hline Below average & $33-40 \%$ \\
\hline Need improvement & $21-32 \%$ \\
\hline Not satisfied & $0-20 \%$ \\
\hline
\end{tabular}

Data was analyzed using percentage, independent sample t-test and one-way analysis of variance
(ANOVA) with SPSS (version 16.0) at 0.05 level of significance. Independent sample t-test and one-way analysis of variance (ANOVA) were employed to find out the differences between the groups on Achievement in Science.

\section{Results \& Discussion}

Objective 1: To study the Achievement of students in Science

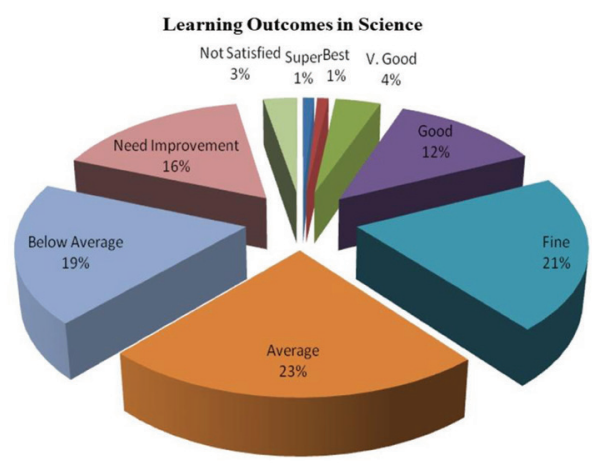

Figure 1: Learning Outcomes in Science of students (in percentage) as per CBSE norms.

Figure 1 depicts the achievement level of the students on SAT. The assessment of achievement has been made on the basis of norm given by CBSE. It is evident from the figure that only $1 \%$ student have achieved in the category of super and best i.e. scored between 91 $100 \%$ and $81-90 \%$ respectively. $12 \%$ of students scored between $71-80 \%$ marks on SAT falling in Good category whereas result of $3 \%$ students was not satisfactory (0$20 \%)$ and $16 \%$ students need improvement (21-32\%). $21 \%$ students scored between $51-60 \%$ (fine), $19 \%$ scored between $33-40 \%$ (below to average) and 23\% students scored between $41-50 \%$ falling in average group.

Before proceeding with the inferential analysis, the data was tested for normal distribution and was found to be normally distributed. The data was then subjected to test the assumptions of t-test and ANOVA, and since all the assumption were met the t-test and ANOVA were calculated for inferential analysis.

Objective 2: To compare mean scores of Science Achievement Test of Male and Female students

Table 1: Difference in Scores of Science Achievement Test on the basis of Gender

\begin{tabular}{|l|l|l|l|l|l|l|l|l|l|}
\hline Variable & Gender & N & Mean & SD & SEM & SEM & t-value & df & Sig. \\
\hline \multirow{2}{*}{$\begin{array}{l}\text { Achievement } \\
\text { in Science }\end{array}$} & Male & 76 & 56.526 & 18.148 & 2.081 & \multirow{2}{*}{4.032} & .090 & 103 & .928 \\
\cline { 2 - 6 } & Female & 29 & 56.889 & 19.314 & 3.586 & & & \multirow{2}{*}{.092} \\
\hline
\end{tabular}


From Table 1, it is evident that the t-value is 34.410 which is significant at 0.05 level with $\mathrm{df}=103$. It shows that the mean of scores in Science Achievement Test of Male and Female students do not differ significantly. It may, therefore, be said the Male and Female students were found to have similar learning outcome on SAT. This result is in congruence with the studies of Olagunju (1998); Olasehinde and Olatoye (2014). Such result may be attributed to similar opportunities in academics that are now provided to both gender, similar classroom environment, teaching methodology. But the studies conducted by Aremu (1999), Okwo and Otunba (2007), Raimi and Adeoye (2002), Toh (1993) have contradicting findings that the male and female students differ significantly on Achievement in Science.

Objective 3: To compare mean scores of Science Achievement Test of Government, Private and Residential school students

Table 2: Difference in Achievement in Science on the basis of Type of School

\begin{tabular}{|l|l|l|l|l|l|}
\hline Source & SS & df & MSS & F-value & Sig. \\
\hline $\begin{array}{l}\text { Between } \\
\text { Group }\end{array}$ & 14161.886 & 2 & 7080.943 & & \\
\cline { 1 - 4 } $\begin{array}{l}\text { Within } \\
\text { Group }\end{array}$ & 20989.719 & 102 & 205.782 & 34.410 & $\mathrm{P}<.001$ \\
\cline { 1 - 3 } & 35151.605 & 104 & & & \\
\hline
\end{tabular}

From Table 2, it is evident that the F-value is statistically significant at $\mathrm{df}(2,102)$ at 0.05 level, therefore, there are significant differences among the students of Government, Private and Residential schools on mean scores of Science Achievement Test. Partial eta squared $\left(\eta_{p}^{2}\right)$ was calculated to estimate the effect size and it was found to be .403 , which shows that the type of school explains $40.3 \%$ variance in scores of Science Achievement Test. To estimate which school has the better learning outcome in multiple comparisons was performed by using Tukey post hoc test.

From Table 3, it can be observed that there is a statistically significant difference among students of government, private and residential school on Achievement in Science, i.e. the students of residential school have better achievement in science than the private school students $(\mathrm{p}<.001)$, they have also performed better than students of government school $(\mathrm{p}<.001)$ and students of government school have better achievement than students of private school $(\mathrm{p}=.015)$. The result is in congruence with the studies conducted by Afzal and Afzal (2015) and Panneerselvam and Muthamizhselvan (2015) that there exists a significant difference between achievement in science between government and private schools. Such results with residential schools students having better learning outcomes in science in comparison with government and private school can be attributed to the specific study time, interaction with senior students to understand concepts after school hours and feeling of cooperation and zeal to help each other among these students.

Table 3: Multiple comparisons among schools on Achievement in science

\begin{tabular}{|l|l|l|l|}
\hline School (I) & School (J) & $\begin{array}{l}\text { Mean } \\
\text { Difference (I-J) }\end{array}$ & Sig. \\
\hline $\begin{array}{l}\text { Government } \\
\text { School }\end{array}$ & Private School & 9.77143 & .015 \\
\hline $\begin{array}{l}\text { Residential } \\
\text { School }\end{array}$ & Private School & 28.02286 & .000 \\
\hline $\begin{array}{l}\text { Residential } \\
\text { School }\end{array}$ & $\begin{array}{l}\text { Government } \\
\text { School }\end{array}$ & 18.25143 & .000 \\
\hline
\end{tabular}

\section{Conclusion}

From above findings, it can be concluded that very few students (18\%) students scored more than 60 percent in science achievement test while 38 percent students scored below average. It shows that most of the students in Chandigarh have low achievement in science at the elementary level. Both male and female students performed same on learning outcome in science. With reference to a type of schools, the students of residential school had better achievement in science in comparison to students of government and private school. It was also found that government school students performed better than private school students.

\section{Implications of the Study}

The invasion of science in our lives had made it essential for us to understand that science is more than the principles and theories prescribed in curriculum. It concerns our daily living thus making science as one of the important components to study for people who actually wants to understand how the knowledge earned in classroom is applied in practical context. 
This brings the focus to Achievement in Science as it becomes one of the important parameters to assess the mastery of content in science in education system. Keeping in view the changes that science is bringing to our lives it is important for every member of society, especially educators and families to develop critical thinking and scientific attitude towards learning and also provide a conducive environment for effective learning.

As found in the results about 23\% students scored average (scores ranging from 41-50\%) and $38 \%$ students have scored even below $40 \%$ as low as $0-20 \%$. This demands attention of teachers, school administration and concerned authorities to look into the reasons why are scoring low in Science. The residential school students have outperformed government and private school students, hence, the model observed in residential schools should be studied and measures should be taken on how the structure followed in residential schools can be applied to the other schools based on the challenges and opportunities of the schools.

The present study was done to assess level of learning outcomes and how these differ among girls and boys and types of school. As extension to this work further researches can be taken up to understand the reasons for such differences and understand the model existing in different schools, so that can be replicated in other schools for better learning outcomes of the students.

\section{References}

Afzal, M.T., \& Afzal, M. (2015). Comparison of students' satisfaction and achievement at secondary level in Islamabad. American Journal of Educational Research, 3(12), 1524-1527.

https://doi.org/10.12691/education-3-12-7

Aremu, S.A. (1999). Games and Primary School Pupils' Achievement in Some Aspect of Geometry (Unpublished doctoral thesis). Department of Teacher Education, University of Ibadan, Ibadan.

Earnest, B.S.P., Bhargava, P., Das, A.K., Azhar, D.T., Ibrahim, N.M., \& Sirisinghe, R.G. (2018). Transforming Teaching-Learning Culture by Appropriate Use of Discrimination Index in Item Analysis. In S.F. Tang
\& S.E. Cheah (Eds.), Redesigning Learning for Greater Social Impact (pp. 159-163). Singapore: Springer. https://doi.org/10.1007/978-981-10-4223-2_14

Kothari, D.S. (1966). Education and National Development: Report of the Education Commission, 1964-66. Ministry of Education, Government of India. Retrieved from https://edufocus.blogspot.com/2017/04/indianeducation-commission-1964-66.html

Narmadha, U., \& Chamundeswari, S. (2013). Attitude towards learning of science and academic achievement in science among students at the secondary level. Journal of Sociological Research, 4(2), 114.

https://doi.org/10.5296/jsr.v4i2.3910

National Research Council (2007). Taking Science to School: Learning and Teaching Science in Grades K-8. Retrieved from https://www.nap.edu/read/11625/chapter/4

Okwo, F.A., \& Otunba, S. (2007). Influence of gender and cognitive styles in science achievement in physics essay test. Journal of Science Teachers Association of Nigeria 42(1\&2), 85-88.

Olagunju, A.M. (1996). The attitude to the use of computer for teaching and learning: implication for science education. Nigerian Journal of Computer Literacy, 1(1), 44-47.

Olasehinde, K.J., \& Olatoye, R.A. (2014). Scientific attitude, attitude to science and science achievement of senior secondary school students in Katsina State, Nigeria. Journal of Educational and Social Research, 4(1), 445-452.

https://doi.org/10.5901/jesr.2014.v4n1p445

Panneerselvam, M., \& Muthamizhselvan, M. (2015). The secondary school students in relation to scientific attitude and Achievement in Science. ISOR Journal of Research \& Method in Education, 5(2), 5-8.

https://doi.org/10.9790/7388-05210508

Raimi, S.A., \& Adeoye, F.A. (2002). Gender difference among college students as determinant of performance in integrated science. African Journal of Educational Research, 8(1\&2), 41-49.

Sahu, B.K. (2012). Statistics in psychology and education. Noida, India: Kalyani Publishers.

Toh, K.A. (1993). Gender and practical tasks in Science. Education Research, 35(3), 255-265. https://doi.org/10.1080/0013188930350304 


\section{旬 \\ CHITKARA}

\section{Issues and Ideas in Education}

Chitkara University, Saraswati Kendra, SCO 160-161, Sector 9-C, Chandigarh, 160009, India

Volume 7, Issue 2

September 2019

ISSN 2320-7655

Copyright: [C 2019 Hem Raj and Fatma Gausiya] This is an Open Access article published in Issues and Ideas in Education (Issues Ideas Educ.) by Chitkara University Publications. It is published with a Creative Commons Attribution- CC-BY 4.0 International License. This license permits unrestricted use, distribution, and reproduction in any medium, provided the original author and source are credited. 